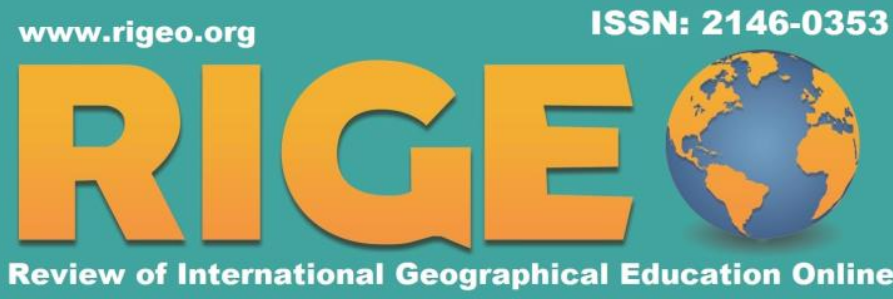

Review of International Geographical Education Online

(c) RIGEO Volume 8, Number 3, Winter 2018

Research Article

Copyright @ RIGEO 2018

To cite this article: Gürgil, F. (2018). Table, Graphic, and Diagram Interpretation and Preparation Skills: Social Studies and Geography Teachers' Practice and Beliefs. Review of International Geographical Education Online (RIGEO), 8(3), 517-541. Retrieved from http://www.rigeo.org/vol8no3/Number3winter/RIGEO-V8-N3-6.pdf

Submitted: July 27,2018

Revised: November 19, 2018

Accepted: December 5, 2018

\title{
Table, Graphic, and Diagram Interpretation and Preparation Skills: Social Studies and Geography Teachers' Practice and Beliefs
}

\author{
Fitnat GÜRGİ́1 \\ Gazi University, Ankara, TURKEY
}

\begin{abstract}
This study aims to determine the views of social studies and geography teachers on their table, graphic, diagram interpretation and preparation skill (TGDI-PS). In according with this study, the research was designed in the mixed method, in which both quantitative and qualitative data collection instruments were used together. The research was conducted with the participation of teachers working in Eskişehir, İstanbul and Ankara (in Turkey) during the 2017-2018 Fall Semester. The quantitative side of the research was made with the participation of 207 teachers from the fields of geography and social studies. The qualitative side of the research was made with the participation of 5 geography and 5 social studies teachers. The data were gathered with the questionnaire and interview forms that were prepared by the researcher. As the result of the analysis of the gathered data, although the views of the teachers on their TGDI-PS were found to be positive, it was found that this did not reflect an implementation. It was concluded that the most important reference for the relevant skills is the textbooks. Furthermore, it was found that tables were given the place in the lessons of the teachers the most and it was followed by graphics, whereas diagram visuals were not given any place in their lessons. In the lessons of social studies and geography, it was found that only the level of 'interpretation/reading' level of TGDI-PS was performed and problems were experienced at the level of 'preperation/drawing'. Under the light of the gathered findings, recommendations were made.
\end{abstract}

Keywords

Social Studies; Geography; Table; Graph; Diagram; Practice; Beliefs

${ }^{1}$ Corresponding author: Research Assistant Dr., Gazi University, Gazi Faculty of Education, Department of Turkish and Social Sciences Education, Beşevler, Ankara, Turkey, E-mail: fgurgil[at]gazi.edu.tr, fitnatgl[at]yahoo.com

(C) Review of International Geographical Education Online

RIGEO 2018

ISSN: 2146-0353

www.rigeo.org 
Humanity's accumulation of knowledge increases incrementally, today. For the education institutions, responsible for transferring the scientific knowledge to new generations, this circumstance causes the problem that knowledge rapidly changes or gets obsolete. For this reason, the mission of the education institutions was redefined in the recent years. Accordingly, the education institutions assumed the mission of equipping the young generations with the skills that they will need throughout their lives, instead of equipping them with the knowledge that rapidly changes and becomes obsolete.

The skill training, started in order to meet the labor need for the industry, took its place in the education systems after the second half of the 20th century (Güneş, 2012). The skill training began to be pronounced more in the Turkish education system after the 2000s, particularly. The skill training is defined in our education system as "the skills that are aimed to be gained and developed in the students throughout the education process" (MoNE, 2005, p. 20). When the curricula of the lessons that are included in the Turkish education system, it is seen that there are the general skills that are common for different lessons as well as some skills that are unique for the lessons. The table, graphic, diagram interpretation and preparation skill (TGDI-PS) is one of the basic skills that are expected to be given to the students by different lessons. 'Table, Graphic, Diagram Preparation and Interpretation' skill is one of the 8 skills that are included in the geography teaching program (MoNE, 2018a). There are 27 skills in the social studies education program. One of these skills is the one, called 'Table, Graphic, Diagram Drawing and Interpretation' (MoNE, 2018b).

TGDI-PS is considered as a skill in social studies and geography programs (MoNE, 2018a, 2018b), but it is considered as a teaching tool or a graphic organizer in the programs of other courses (MoNE, 2018c, 2018d, and 2018e). Therefore, it cannot be said that there is a unity in the literature. Hall \& Strangman (2008, p.2) describe graphic organizers as 'visual and graphic display that describe the relationships between facts, terms and ideas', while Rice (1994) describes graphic organizers as 'two-dimensional visual sequences showing the relationships among concepts' (cited in Monroe, 1997, p.5). The conducted researches present that this skill provides a lot of benefits to the students and teachers in various fields. The advantages of using table, graphic and diagram in the education process can be summarized, as such:

Using table, graphic and diagram;

- Makes understanding easier (Alvermann \& Boothby, 1986; Bean, Singer, Sorter \& Frazee,1986; Ben-David, 2002; Dönmez, Yazıc1 \& Sabanc1, 2007; Dunston, 1991; Gieselmann, 2008; Monroe, 1997; Simmons, Griffin \& Kameenui, 1988; Sönmez \& Koç, 2013; Yazıc1, 2006; Zaini et al., 2010).

- Makes remembering easier (Ben-David, 2002; Dönmez et.al., 2007; Dunston, 1991; Griffin, Malone \& Kameenui, 1995; Gieselmann, 2008; Kohler, 2009; Simmons et.al., 1988).

- Improves vocabulary (Ben-David, 2002; Gieselmann, 2008; Monroe, 1997). 
-Visualizes knowledge (Ben-David, 2002; Cassidy, 1989; Dönmez et.al., 2007; Dunston, 1991; Gieselmann, 2008; Hall, Kent, McCulley, Davis \& Wanzek, 2013; Sönmez \& Koç, 2013; Zaini et al., 2010).

- Materializes abstract information (Hall et al., 2013; Kohler, 2009; Sönmez \& Koç, 2013; Şahin, Gençtürk \& Budanur, 2007).

- Improves students' prediction skill (Dunston, 1991; Kohler, 2009).

-Shows relations between concepts (Ben-David, 2002; Cassidy, 1989; Dönmez et.al., 2007; Dunston, 1991; Hall et al., 2013; Zaini et al., 2010).

-Allows detecting misconceptions (Ben-David, 2002; Zaini et al., 2010).

- Allows relating the past information with the new one (Ben-David, 2002; Cassidy, 1989; Dönmez et.al., 2007; Dunston, 1991; Hall et al., 2013; Kohler, 2009; Zaini et al., 2010).

- Improves critical thinking skill (Ben-David, 2002; Cassidy, 1989; Gieselmann, 2008; Maden \& Altunbay, 2016; Shah \& Hoeffner, 2002; Zaini et al., 2010).

- Improves problem solving skill (Kohler, 2009; Oruç, Uğurlu \& Tokcan, 2010; Zollman, 2009).

- Improves the skill of perceiving change and continuity (Zaini et al., 2010).

-Allows generalization by showing evidence (Kohler, 2009; Sönmez \& Koç, 2013; Zaini et al., 2010).

-Develops comparison skill (Hall et al., 2013; Sönmez \& Koç, 2013; Şahin et al., 2007).

- Contributes in the improvement of basic mathematics skill (Zollman, 2009).

- Provides preparation for the lesson by presenting preliminary information in starting to a new topic (Dönmez et. al., 2007).

- Allows to summarize the learned knowledge (Dönmez et. al., 2007; Sezer, 2017).

- Allows effectively using time (Dönmez et. al., 2007).

- Improves students' motivation by drawing their attention to the lesson (Dönmez et. al., 2007; Hawk, 1986; Sezer, 2017; Zaini et al., 2010).

- Prevents the lessons' becoming monotonous (Dönmez et. al., 2007; Hawk, 1986).

-Enriches the education environment (Sönmez \& Koç, 2013).

- Is low-cost (Hawk, 1986).

- Is suitable for the students, with different learning types (Ben-David, 2002; Sezer, 2017; Zaini et al., 2010; Zollman, 2009). 
- Is a convenient tool for the presentation of both social and natural science data (Maden \& Altunbay, 2016; Sezer, 2017; Shah \& Hoeffner, 2002; Oruç, et al., 2010).

Being both a skill and an education tool, the tables, graphics and diagrams gives many advantages to the teachers and students in the learning-teaching process as it is seen above. According to Şahin, Gençtürk and Budanur (2007), however perfect an education tool is the main point that determines its success is the teachers' knowledge and usage method. The teachers' lack of knowledge or of related skill about knowing how to use it will interrupt the expected success.

In the literature, there are different views on the question of "How should be the training of this skill that has many advantages in the learning process?" Sezer (2017, p. 177) refers to a gradual process about learning the TGDI-PS. This process starts with finding the data that individuals are going to use in the table, graphic and diagram visuals. In this stage, if possible, especially the primary sources must be accessed. The type of the graphic organizers (table, graphic, diagram) and their variety (pie chart, column chart etc.) must be determined and the data must be put on the graphic organizers in a correct manner. After the preparation of the graphic organizers, a title must be given to the study. Finally, the training process of this skill must be completed with the statement of the used sources.

According to Cassidy (1989), this skill must be trained in 5 phases, as explanation, modeling, application, reflection and independent application. The phases that Cassidy $(1989$, p. 34) summarized, as such: First of all, the graphic organizers must be explained to the students with all of their aspects and it must be ensured that their importance is understood. A model sample must be created on a known subject. Afterward, an opportunity must be given to the students to apply in a known topic first and then a new learned one by separating them into groups. It must be requested from the students to present the prepared models in the class and again evaluate themselves. And finally, the teachers must give their students assignments about graphic organizers in different subjects that they can make alone.

According to Shah \& Hoeffner (2002), the teachers must primarily choose the type of graphic organizer, convenient for data. The teachers must determine the most convenient visual by converting the same data into different formats. Again, the teachers must apply to the animations when it is necessary and avoid from them when they are not needed. Because, the unnecessary use of animation will distract students and make it harder for them to learn. Furthermore, the teachers must simply the visual presentation by reducing the unnecessary data. Again, the teachers must pay attention to the transition between colors that are used for the data. Finally, the teachers must check the suitability of the visual presentation and the text (Shah \& Hoeffner, 2002 referring to Kosslyn, 1994 \& Tufte, 1983; p. 62-63).

In the development of the same skill, there are also important points that must be paid attention in the in-class applications for the teachers. Hall et al. (2013) and Sezer (2017) advices the teachers to use ready-made graphic organizers in the acquisition of the given skill. In time, the teachers should slowly draw themselves back and provide an 
opportunity for the students to create graphic organizers on their own. In the Turkish education system, the students are expected to read/interpret ready-made tables, graphics and diagrams more in the first grades, while being expected to prepare their own visuals in the higher classes (MoNE, 2005). According to Sezer (2017), one of the important points in the acquisition of this skill is turning the tables, graphics and diagrams into texts as much as turning the texts into the tables, graphics and diagrams. Sönmez and Koç (2013) suggest that the teachers should use the related skill activities in their classes from simple to complex ones in each class level. Maden and Altunbay (2016) emphasize the importance of giving an instruction to the students in the skill acquisition and of the clearness and understandability of them.

The graphic organizers that are used in the education environments are the tools that are convenient for learning individually or in groups (Dönmez et al., 2007; Zaini et al., 2010). For this reason, a place must be given to this skill as a group assignment as much as individual ones. It is also recommended for teachers to frequently give place to this skill in their assessment and evaluation activities. Moore \& Readence (1984) say that the success of the graphic organizers is in direct proportion to the duration of education. Consequently, that the teachers give place to the TGDI-PS in every convenient topic will be effective in acquiring these skills. According to Ping (2016), suggesting using the graphic organizers in the topics that intensely contain knowledge, the graphic organizers increases the understandability of the complex texts by allowing students to see the whole of the topic. The use of more than one graphic organizers in the contents of especially long and complex lessons is also recommended in the literature (Robinson, 1997; Zaini et al., 2010).

The tables, graphics and diagrams were the topics of many researches thanks to the benefits that they provide both for the students and teachers. In the literature it is seen that there are the study of (Meyer, 1995) was made in terms of reading and writing; (Aydın \& Tarakç1, 2018; Casteleyn \& Mottart, 2012; Hawk, 1986; Knight, Spooner, Browder, Smith \& Wood, 2013; Taşdemir, Demirbaş \& Bozdoğan, 2005) in science; (Braselton \& Decker, 1994; Ives \& Hoy, 2003; Memnun-Sezgin, 2013; Monroe, 1997; Yavuz \& Kepceoğlu, 2010; Zollman, 2009) in mathematics; (Jiang, 2012) in foreign language learning; (Demirci \& Uyanık, 2009) in physics; (Gültekin \& Nakiboğlu, 2015) in chemistry; (Bean et al., 1986) in history; (Budanur, 2004; Şahin et al., 2007) in geograhy; and (Alvermann \& Boothby, 1986; Bektaş-Öztaşkıran, 2014; Boothby \& Alvermann, 1984; Darch, Carnine \& Kameenui, 1986; Doyle, 1999; Dönmez et al., 2007; Gallavan \& Kottler, 2007; Griffin et al., 1995; İlter, 2016; Oruç \& Akgün, 2010; Oruç et al., 2010; Schenning, Knight \& Spooner, 2013) in social studies.

According to Taş (2008), the most important task belongs to the teacher in skill acquisition. Being the applier of the lesson, the teachers are seen to be important in terms of determining the views, concerns and the problems that they confront about the interpretation and preparation of the tables, graphics and diagrams and in terms of determining the suggestions about this subject as well as the improvement of the related lesson materials. When the studies in the literature are examined, it was determined that the studies, in which the teachers' point of views are taken, were quite limited in number. The related skill is one of those which is included within the scope of both 
social studies and geography lessons. In the literature, there is not any study, in which the views of the social studies and geography teachers were taken and compared. In this respect, it is thought that this study will give ideas for the future studies by filling the gap in the literature.

Within this scope, the purpose of this study is to investigate the social studies and geography teachers' practices and beliefs about TGDI-PS. In accordance with this purpose, the answers of the following questions were sought:

- What are the views of the social studies and geography teachers on their TGDIPS?

- Do the views of the social studies and geography teachers on their TGDI-PS change according to their gender, to their academic field, to their professional seniority differences?

- In the teaching of which subjects do the social studies and geography teachers use the TGDI-PS, and what do they do to improve this skill?

- What are the difficulties that the social studies and geography teachers confront in teaching TGDI-PS?

- What do the social studies and geography teachers recommend on having students acquire the TGDI-PS more efficiently?

\section{Method}

In this study, the mixed method, in which the different data collection tools were utilized, was used in order to determine the views of the social studies and geography teachers about the TGDI-PS in a more detailed and comprehensive manner (Creswell \& Clark, 2007; Johnson, Onwuegbuzie \& Turner, 2007).

\section{Research Design}

In the study, the explanatory sequential design, one of the mixed method designs is used. In this research design, firstly, the quantitative data are collected and analyzed. Then, qualitative data collection tools are used for elucidation and elaboration of the quantitative data. Since the collection of qualitative data is followed by the quantitative data collection, this method is called "sequential" (Creswell \& Clark, 2007). With the questionnaire form that was prepared by the researcher, the quantitative data were collected and analyzed for the first time in the study. After the analysis of the quantitative data, the qualitative data were collected and analyzed in the semi-structured interview approach. This study adopts the mixed method with an aim to obtain a richer data set, to support and explain the data obtained, and to clarify the contradictory points in the data more easily.

\section{Participants}

In this study, there were two different participant groups. In the quantitative section of the study, 207 social studies $(n=105)$ and geography $(n=102)$ teachers - working in 
İstanbul, Eskişehir and Ankara in the education term of 2017-2018 - participated. The teachers' information was displayed in Table 1.

Table 1

The Teachers' Information That Is Contained in the Questionnaire Data

\begin{tabular}{|c|c|c|c|c|c|}
\hline & & \multicolumn{2}{|c|}{ Geography } & \multicolumn{2}{|c|}{$\begin{array}{l}\text { Social } \\
\text { Studies }\end{array}$} \\
\hline & & $f$ & $\%$ & $f$ & $\%$ \\
\hline \multirow[t]{3}{*}{ Gender } & Female & 59 & 58 & 65 & 62 \\
\hline & Male & 43 & 42 & 40 & 38 \\
\hline & Total & 102 & 100 & 105 & 100 \\
\hline \multirow{6}{*}{$\begin{array}{l}\text { Professional } \\
\text { Seniority }\end{array}$} & $0-5$ years & 34 & 33 & 37 & 35 \\
\hline & $6-10$ years & 25 & 24 & 26 & 25 \\
\hline & $11-15$ years & 22 & 22 & 14 & 13.3 \\
\hline & $16-20$ years & 13 & 13 & 15 & 14.3 \\
\hline & 21 years and above & 8 & 8 & 13 & 12.4 \\
\hline & Total & 102 & 100 & 105 & 100 \\
\hline
\end{tabular}

207 teachers, who filled out the questionnaire form in the research, were consisted of 124 female and 83 male. In other words, $60 \%$ of the teachers, who filled out the questionnaire form, were female teachers. When the professional seniority levels of the teachers, participating in the research, was examined, it was seen that more than half of them $(n=122)$ was consisted of the teachers, who had the rank of 10 years and below. The number of teachers, who have the professional seniority of 21 years or above which could be considered to be the highest experience level in terms of the professional seniority, was 21 . This number corresponds to almost $10 \%$ of the participating teachers in terms of their professional seniority levels.

The questionnaires were personally delivered to the teachers by the researcher. The researcher was in the same environment as the teachers when they were completing the questionnaire to be able to help them when needed. The information regarding the purpose of the questionnaire, which subject teachers it involves, the average number of minutes it takes to complete was explained to the participating teachers. In addition, they were told that the information given would be used only within the scope of the research, and the identities would be kept confidential. After the questionnaires were filled out, the teachers were informed about the second phase of the study. The teachers 
were asked whether they would like to participate in the second phase of the research (in the semi-structured interviews). The contact details of the teachers who wanted to participate in the interviews were obtained, and the appropriate interview dates were determined. The information about the teachers participating in the semi-structured interviews are given in Table 2.

Table 2

Information about the Teachers Participating in the Semi-Structured Interviews

\begin{tabular}{|c|c|c|c|c|c|}
\hline & & \multicolumn{2}{|c|}{ Geography } & \multicolumn{2}{|c|}{ Social Studies } \\
\hline & & $f$ & $\%$ & $f$ & $\%$ \\
\hline \multirow[t]{3}{*}{ Gender } & Female & 4 & 80 & 3 & 60 \\
\hline & Male & 1 & 20 & 2 & 40 \\
\hline & Total & 5 & 100 & 5 & 100 \\
\hline \multirow{6}{*}{$\begin{array}{l}\text { Professional } \\
\text { Seniority }\end{array}$} & $0-5$ years & 1 & 20 & 1 & 20 \\
\hline & $6-10$ years & 1 & 20 & 1 & 20 \\
\hline & $11-15$ years & 1 & 20 & 1 & 20 \\
\hline & $16-20$ years & 1 & 20 & 1 & 20 \\
\hline & 21 years and above & 1 & 20 & 1 & 20 \\
\hline & Total & 5 & 100 & 5 & 100 \\
\hline
\end{tabular}

The interviews were conducted with 10 teachers selected from among those who volunteered to take part in the semi-structured interviews $(n=43)$, who were considered to be most suitable in terms of subject (geography $n=5$; social studies $n=5$ ) and professional seniority (at least 1 teacher representing each seniority). Three of the teachers work in İstanbul, three in Eskişehir, and four in Ankara. 70\% of the teachers, who participated in the semi-structured interview approach, was female $(n=7)$, and $30 \%$ male $(n=3)$. In the study, it was paid attention that at least one participant, representing each professional seniority level from the geography and social studies fields, took place.

\section{Data Collection Instruments}

The questionnaire form. In order to prepare the study's quantitative data collection instrument, the literature was searched and a draft form was prepared in the type of five point Likert scale. The draft form was consisted of two parts. While the personal information of the participants was given place in the first part, 27 expressions 
about the TGDI-PS were given place in the second place. The prepared draft form was presented for the approval of an academic member, assigned at the department of social studies teaching of a state university, and of an academic member, assigned at the department of geography teaching. Furthermore, the draft form was presented to the approval of a social studies teacher, a geography teacher and a language expert who serve in Kocaeli. According to the feedbacks of the experts, two questions were merged together and four questions were removed from the questionnaire form. 87 teachers participated in the pilot scheme of the prepared questionnaire (social studies $n=51$, geography $\mathrm{n}=36$ ). As the result of the analysis, Cronbach's Alpha value was found to be .748 .

Semi-structured interview form. Prepared by the researcher, the interview form was presented to the approval of the academic members, assigned at the same university. In parallel with the expert feedbacks, the interview form was corrected. In the prepared form, 4 questions were given place. 2 geography and 2 social studies teachers participated in the pilot application of the interview form. After the pilot application, the interview form was given its final form and the real application was made.

\section{Data Analysis}

Expert opinions were consulted to ensure the scope and face validity of the prepared questionnaire. In addition, the piloting was carried out with another group of teachers ( $\mathrm{n}$ = 87) with similar characteristics to the group participating in the main study. The item means of each item that takes place in the questionnaire form were analyzed and interpreted in order to determine the views of the geography and social studies teachers on the TGDI-PS. The means that were taken according to the responses to the items were evaluated within the following limits: 1.00-1.79: I Certainly Agree; 1.80-2.59: I Agree; 2.60-3.39: I am Indecisive; 3.40-4.19: I Disagree and 4.20-5.00: I Certainly Disagree.

In order to analyze whether the views of the geography and social studies teachers on the TGDI-PS change according to their gender differences and specific fields, the independent samples t-test was used. In order to examine whether the views of the teachers change according to their differences in professional seniority levels, the analysis of variance (ANOVA) was used. In order to determine at which level the independent variable that is obtained as the result of the analysis of variance exists, Tukey test, one of the post-hoc tests, was used as the homogeneity of the variances was provided. In order to test the normal distribution assumption, skewness-kurtosis coefficients were examined. In order to examine the assumption of variances homogeneity, Levene statistics was calculated.

To the teachers, filling out the questionnaire forms of the study, the second part of the study was explained. The rendezvous dates were decided by taking the contact information of the teachers who want to participate in the qualitative part of the study. The interviews were recorded with a recorder by taking the permission of the teachers. The answers of the teachers were transferred to the electronic environment. The content 
analysis was applied in the analysis of the data. The interview forms that were made with the teachers were coded after being read more than once. The codes that express the similar things were merged and categories were created. In the analysis of the qualitative data, the reliability formula, developed by Miles and Huberman (1994, p.64) was used by taking support from a second coder. The consistency between coding was found to be $97 \%$. By abiding by the ethical rules of the study, each participant's field, professional seniority, and gender were used as codes, instead of their identity information. One part of the participants' views are presented in the findings part as direct quotations.

\section{Findings}

\section{Findings Emerging from the Quantitative Data}

The means and the standard deviation of the answers of the teachers to the items that are included in the questionnaire form which was prepared in order to examine the social studies and geography teachers' views on the TGDI-PS were calculated. The results are presented in Table 3.

Table 3

Means and Standard Deviations of the Table, Graphic and Diagram Interpretation and Preparation Skills (TGDI-PS)

\begin{tabular}{lll}
\hline Items & $\overline{\boldsymbol{X}}$ & Ss \\
\hline $\begin{array}{l}\text { 1. The TGDI-PS is one of the important skills in terms of the } \\
\text { development of the students. }\end{array}$ & 1.40 & 0.59 \\
\hline $\begin{array}{l}\text { 2. In the teaching areas and outcomes of the education program, the } \\
\text { TGDI-PS should have been given place, more. }\end{array}$ & 1.67 & 0.99 \\
\hline $\begin{array}{l}\text { 3. In the activities in the textbooks, the TGDI-PS should have been } \\
\text { given place, more. }\end{array}$ & 1.79 & 1.11 \\
\hline $\begin{array}{l}\text { 4. The content of the TGDI-PS activities that are given place in the } \\
\text { lesson books is consisted of the updated data. }\end{array}$ & 2.52 & 1.26 \\
\hline $\begin{array}{l}\text { 5. The TGDI-PS that is given place in the lesson books and education } \\
\text { programs was prepared according to the age of the students. }\end{array}$ & 1.98 & 0.89 \\
\hline $\begin{array}{l}\text { 6. The TGDI-PS was distributed between classes in a balanced } \\
\text { manner. }\end{array}$ & 3.00 & 1.37 \\
\hline $\begin{array}{l}\text { 7. I always prepare tables for my lessons. } \\
\text { 8. I always prepare graphics for my lessons. }\end{array}$ & 2.62 & 0.81 \\
\hline 9. I always prepare diagrams for my lessons. & 3.76 & 1.01 \\
\hline 10. I always have my students prepare tables for my lessons. & 3.15 & 0.90 \\
\hline 11. I always have my students prepare graphics for my lessons. & 1.05 \\
\hline 12. I always have my students prepare diagrams for my lessons. & 3.95 & 1.01 \\
\hline 13. In the activities to allow my students to acquire the TGDI-PS, I \\
take the personal differences (learning differences) of the students \\
into consideration.
\end{tabular}


seminars for having the TGDI-PS 1 acquired are increased.

\begin{tabular}{llll}
\hline 16. The TGDI-PS draws the students' attention. & 1.68 & 0.84
\end{tabular}

\begin{tabular}{llll} 
17. The TGDI-PS provides active participation in the lesson. & 2.51 & 0.95 \\
\hline
\end{tabular}

18. The TGDI-PS contributes in lasting learning by helping the $1.53 \quad 0.65$ materialization of abstract subjects.

19. The TGDI-PS contributes in the development of the skill of 2.341 .27 creativity.

20. The TGDI-PS contributes in the development of the skill of critical thinking.

21. The TGDI-PS contributes in the development of the skill of problem solving.

$1.58 \quad 0.60$

22. The TGDI-PS contributes in the development of the skill of $1.57 \quad 0.66$
perception of continuity.

When we examined Table 3, it is seen that the items of " $1,2,3,13,16,18,21$ and 22 " were answered at the level of 'I Certainly Agree' ( $\overline{\mathrm{X}}=1.00-1.79)$. The answer given to the items of " $4,5,7,10,14,15,17,19$ and 20 " was at the level of 'I Agree' ( $\overline{\mathrm{X}}=1.80$ 2.59). It is seen that the participants gave the answer to the items of " 6,8 and 11 " at the level of 'I am Indecisive' ( $\overline{\mathrm{X}}=2.60-3.39)$. It was found that the participants gave the answer to the items of " 9 and 12 " in the same questionnaire at the level of 'I Disagree' $(\overline{\mathrm{X}}=3.40-4.19)$.

According to the analyses, the social studies and geography teachers consider the TGDI-PS important for the development of the students. On the opposite, the teachers stated that the outcomes and the learning areas on this matter in the education programs and textbooks were not sufficient and had to be improved. The teachers stated that this skill drew the students' attraction and contributed in lasting learning by materializing the abstract subjects. Again the teachers concentrated on the view that the related skill contributed in the development of the high-level thinking skills. It was found that the participant teachers take the students' personal differences into consideration in their activities toward the TGDI-PS.

In addition, it was found that the teachers prepared tables for their lessons and also had their students prepare tables. It was found that the participant teachers were indecisive in the item 'I always prepare materials for my lessons and have my students prepare graphics'. It was also found that the teachers did not agree with the items of ' $I$ always prepare diagrams for my lessons and have my students prepare diagrams'. Although it was found that the teachers felt themselves sufficient in terms of having the students acquire the TGDI-PS, it was seen that they wanted the number of the in-service trainings and seminars on these topics to be increased.

As the normal distribution assumption was provided in order to examine whether the social studies and geography teachers' views on the TGDI-PS differed according to their genders, the independent samples t-test was used. The results are presented in Table 4. 
Gürgil, F. (2018) / Table, Graphic, and Diagram Interpretation and Preparation Skills: Social Studies....

Table 4

Analysis of the Views of the Social Studies and Geography Teachers on Their Table, Graphic, Diagram Interpretation and Preparation Skill According to Their Gender Differences

\begin{tabular}{lllllll}
\hline & $\mathbf{n}$ & $\overline{\boldsymbol{x}}$ & ss & sd & $\mathbf{t}$ & $\mathbf{p}$ \\
\hline Female & 124 & 48.83 & 8.28 & & & \\
\hline Male & 83 & 50.18 & 9.35 & & 1.091 & 0.277 \\
\hline
\end{tabular}

When Table 4 is examined, it is seen that the points which the social studies and geography teachers took from the 'Questionnaire of Table, Graphic, Diagram Interpretation and Preparation Skill' did not show any statistically significant difference according to their genders ( $p>0.05)$. When the means score were examined, it is seen that the points that the male received from the 'Questionnaire of Table, Graphic, Diagram Interpretation and Preparation Skill' was a little bit higher than the points of the female. In other words, the male teachers had more positive views on the TGDI-PS, compared to the female teachers. However, this finding is not statistically significant.

In order to examine whether the social studies and geography teachers' views on the table, graphic, diagram interpretation and preparation skill differed according to the differences in their fields, the independent samples t-test was used. The results are presented in Table 5.

Table 5

Analysis of the Views of the Social Studies and Geography Teachers on Their Table, Graphic, Diagram Interpretation and Preparation Skill According to Their Field Differences

\begin{tabular}{lllllll}
\hline & $\mathbf{n}$ & $\overline{\boldsymbol{x}}$ & $\mathbf{s s}$ & $\mathbf{s d}$ & $\mathbf{t}$ & $\mathbf{p}$ \\
\hline Geography & 102 & 45.36 & 6.57 & & & \\
\hline Social Studies & 105 & 53.27 & 8.83 & & & \\
\hline & & & & & \\
\hline & & & \\
& & & \\
$\mathrm{p}<0.05$ &
\end{tabular}

When Table 5 is examined, it is seen that the points which the social studies and geography teachers took from the 'Questionnaire of Table, Graphic, Diagram Interpretation and Preparation Skill' showed statistically significant difference according to their differences in fields $(\mathrm{p}<0.05)$. When the means score were examined, it is seen that the points that the social studies teachers received from the 'Questionnaire of Table, Graphic, Diagram Interpretation and Preparation Skill' was higher than the points of the geography teachers. As can be seen in the Table 5, the mean score indicated that the social studies teachers have more positive views on the TGDI-PS, in comparison to the geography teachers. 
As the normal distribution assumption was provided in order to examine whether the social studies and geography teachers' views on the TGDI-PS differed according to their professional seniority levels, the analysis of variance (ANOVA) was used. The results are presented in Table 6.

Table 6

Analysis of the Views of the Social Studies and Geography Teachers on Their Table, Graphic, Diagram Interpretation and Preparation Skill According to Their Professional Seniority Levels

\begin{tabular}{|c|c|c|c|c|c|c|}
\hline & $\mathbf{n}$ & $\overline{\boldsymbol{X}}$ & SS & sd & $\mathbf{F}$ & $\mathbf{p}$ \\
\hline 0-5 years & 71 & 48.38 & 8.19 & \multirow{5}{*}{$(4.202)$} & \multirow{5}{*}{$3.945^{*}$} & \multirow{5}{*}{0.004} \\
\hline 6-10 years & 51 & 49.04 & 8.64 & & & \\
\hline $11-15$ years & 36 & 46.61 & 9.46 & & & \\
\hline $16-20$ years & 28 & 52.11 & 8.85 & & & \\
\hline $\begin{array}{l}21 \text { years and } \\
\text { above }\end{array}$ & 21 & 54.62 & 6.64 & & & \\
\hline
\end{tabular}

When Table 6 is examined, it is seen that the points which the social studies and geography teachers took from the 'Questionnaire of Table, Graphic, Diagram Interpretation and Preparation Skill' showed statistically significant difference according to their professional seniority levels $(\mathrm{p}<0.05)$. In order to determine between which levels of the professional seniority the determined difference is, a paired comparison was made. As the homogeneity assumption of the variances was provided, Tukey test was used among the post-hoc tests in order to make a paired comparison. As the result of the comparisons, it was found that there was a difference in the points that the teachers took from the "Questionnaire of Table, Graphic, Diagram Interpretation and Preparation Skill" between the teachers, with 0-5 years and 11-15 years of professional seniority, and those, with 21 years and above. When the means score were examined, it was found that the points of the teachers, with the professional seniority of 21 years and above, were higher than those, having 0-5 and 11-15 years of professional seniority.

\section{Findings Emerging from the Qualitative Data}

In this part of the study, the qualitative findings, containing the semi-structured interview data, were given place.

The subjects social studies and geography teachers use TGDI-PS to teach, and their practices to improve this skill. It was asked to the interviewed teachers what were they doing for the development of the TGDI-PS in the curricula of their own fields. When the views of the teachers were examined, it was found that few 
teachers were knowledgeable in this matter - regardless of their differences of fields. In the acquisition of this skill, it was found that most of the teachers adhered to the textbooks and did not make any extra efforts to create different resources. For example, a teacher made the following statements:

"I do not make a lot of things. There are enough in the textbook. We are using them. Sometimes, I take a table from the auxiliary sources if I see when taking an exam question. I think it is an important course material. However, there are very few sources that a teacher can use for them (Geography, 16-20 Years, Male)."

According to the statements of the teachers, the highest number of the materials used in their lessons belonged to the table visuals, and the graphic visuals followed it. Again according to the statements of the teachers, the diagrams were either not used or used very little both in the geography and social studies lessons. And a teacher stated that this skill was related to the mathematics skill, so the mathematic teacher's effort is important at his own class. The teacher's opinion on this subject is as follows:

"I cannot say that I am paying a lot of attention (...) I use the tables and graphics in the textbook. I do not think it is so much about the social studies lesson, either. I think this skill will help students in calculation-requiring tasks. I think it is more of a subject of the mathematics. The mathematics teachers must pay attention; we mention it if it is related to the topic, of course. But what is important for use is learning the information contained in the social studies, these [tables, graphics, diagrams] are just materials that are used in the education of this information. Our job is not the tables, graphics already. The mathematics teacher must teach them [table, graphic, diagram skill] (...) (Social Studies, 11-15 Years, Male).”

Some of the teachers stated that they did not feel competent, although they did not make any special effort for the TGDI-PS. The views of some of the participants that give this statement are as follows:

"I am using the textbook, so I do not make a very special effort. But this is not like this for only me. I think there is a general insufficiency in this matter. I do not think I took enough training in this matter, also. Sometimes, I have also difficulties in these questions [table, graphic and diagram questions]. I think it is about the fact that we were not well-trained in general. None of our professors mentioned this at the university. Not any training was also provided for the teachers. So the result is obvious (!) (Social Studies, 6-10 Years, Female)". "I also ask the tables and graphics that are similar to the ones given in the textbook in the exams. But I cannot prepare a very complex graphic, for example. And diagrams, because they are few in the textbooks, I cannot say that I use them. I think that I need a good training in this matter (...) (Geography, 11-15 Years, Female)."

One of the teachers stated that she was not competent enough in the information technologies due to her old age, so she makes do with the examples in the textbooks for the development of the TGDI-PS. The view of the teacher as such: 
"Unfortunately, I have got old. These are all created on the computer. And I cannot use the computers as well as you do. This is why I am using the ones in the textbook (...) (Social Studies, 21 Years and Above, Female)."

Only one of the teachers who participated in the interview explained the applications that she made in order to develop this skill in her students. The teacher's views are as follows:

"In this matter, I use different methods according to the students' level. In the 9th grades, I am trying to teach the basics, more. Because our students are coming from different secondary schools and most of them do not have any backgrounds. While the students should have acquired this skill before, we have to teach the basics in the 9th grade. These basics can be postponed to the 10th grade for some of the students. After the 10th grade, I am trying to go beyond interpretation. I am doing things that a slightly different. (...) For example, I am taking the updated information from the websites of such institutions as the TSI (Turkish Statistics Institute) and the United Nations and giving them to the students as an assignment. I ask them to create a table, graphic. Most students like that. But I need to teach the basic concepts to the students and how they need to evaluate something, how they need to put something in. Then, I want them to create their own graphics and tables. The students enjoy a lot when they are explaining their own graphics. Why did they take the numbers in the graphics, where did they take it from, is their purpose the differences between data or change in the process? When they explain those, the information happens to be more lasting. I think it is because the student structurize his own knowledge (Geography, 6-10 Years, Female)."

The question of in which topics the teachers use the TGDI-PS the most was asked to the participant teachers as another question. It can be said that the fields of the teachers are determinant in this matter. All of the social studies teachers stated that they benefited from the TGDI-PS in terms of population and settlement, the most. For example, a teacher made the following statements: "I am using in the units about geography, the most. For example, I am using it in the topics about population (...) (Social Studies, 0-5 Years, Male)."

One of the social studies teachers stated that she used the TGDI-PS in the topic of economic activities, apart from population and settlement. The teacher's opinion on this subject is as follows:

"I am using the topics in the population and settlement activities, the most. (...) Sometimes, I am using them in the topics like agriculture and livestock. Sometimes books give us a hint. In these units, there are many tables and graphics. You are having students make them unavoidably (Social Studies, 16-20 Years, Female)."

It was found that the geography teachers gave answers to the same questions with more diversity. It was observed that most of the geography teachers $(n=4)$ took the class 
levels into consideration while expressing their thoughts on this issue. While a teacher makes the following statements:

"I am trying to use almost in every topic. I frequently use in the topics of population, settlement, production-distribution and consumption (...) In fact, most of the topics of geography are convenient. Most of the students did not get out of their own small environment. They think the world is limited with their own environment. Crude information is not shaped in the students' heads sometimes. I think, the graphics, and especially tables, are affective in the students' learning these topics (Geography, 0-5 Years, Female)."

Another geography teacher came up with the following explanation:

"I, for instance, taught to 11th grades and I can say that I used them in every topic. One certainly uses both tables and graphics in every topic from agriculture, livestock, tourism, mining, industry, commerce (...) to whatever you comes to your mind (Geography, 16-20 Years, Male)."

Another geography teacher explained the subjects which include the table, graph, and diagram preparation skills according to the grade level.

"The climate graphics are one of the topics that we frequently use in the 9th grades. Also I use tables about the vegetation, every year. I have population graphics for the 10th grades, I also have tables every year; I use them for the 11th grades in every matter, related to economy. In all of the agricultural and livestock data, commercial data, land-sea-air transportation, I use graphics and tables (...) (Geography, 6-10 Years, Female)."

The challenges encountered by social studies and geography teachers in the teaching of TGDI-PS. The difficulties that the teachers confront in teaching the TGDI-PS were directed to the teachers as another question. Generally, the difficulties that the geography teachers remarked are the shortcomings lack of prior knowledge the students, insufficiency of the weekly lessons and intensity of the education program. For example, a teacher made the following statements:

"I think the students do not come with enough background. So, we are spending effort to close that gap. This time, the effort that we needed to spend in the 9th and 10th grades happens to be gone for other things. And the curriculum of the geography lesson is already too wide. Additionally, our lesson hours are very insufficient. (...) (Geography, 6-10 Years, Female)."

And the last difficulty remarked by the geography teachers is the indifference of the students toward this skill. A teacher's thoughts on this subject are as follows:

"I get angry the most when a student does not know the topic and does not allow his friends to listen while he himself does not know, either (...) If the student is indifferent, we cannot do anything. This situation created weariness for me, also. There are some students, resisting not to learn anything regardless of whatever you do. They prevent their friends from learning, as well. When we also are in rush to finish the topics, we cannot provide place to this type of instruments. The 
hours of our lessons are too few. Some lessons have many hours, but the topics to study are very few. There is a completely reverse situation in geography (Geography, 11-15 Years, Female)."

According to the interview data, the difficulties that the social studies teachers confront are the lack of materials related to the given skill, the insufficiency of the teachers and the crowdedness of the classes. One of the social studies teachers drawing attention to the difficulties in finding materials and feeling inadequate in material preparation said:

"Frankly, I have difficulties in terms of materials. I cannot use a material, except for the textbooks and auxiliary sources. Also, I do not know how to prepare (...) (Social Studies, 6-10 Years, Female).”

A social studies teacher who said that he was having trouble finding different types of material also explained:

“(...) I cannot access different types of graphics and diagrams. After all, I would use them more if there were colorful and different materials. But for example, there are only tables in the books. I sometimes find column chart and pie charts. However, there are not any diagrams. But I see that there are various graphics, diagrams in the books of the foreigners, we do not have them. We also do not know how it is made. If it is taught to the teachers, maybe we can also do that (Social Studies, 0-5 Years, Male)."

Again, a teacher highlighted overcrowded classes as a difficulty in teaching. Some views of the teacher are as follows: "(...) how can it be taught to the entire classroom! While teaching one of them, others do not stand still. The classes are very crowded! (...) (Social Studies, 16-20 Years, Female)."

Recommendations by social studies and geography teachers to teach TGDI-PS more effectively. As the final question, it was asked what the teachers' suggestions are in order to have the given skill acquired at the desired level. The suggestion of most of the teachers was to increase the lesson hours. For example, a teacher's thoughts on this subject are as follows:

"(...) the hours of our lessons are not enough when we have too many topics. In my opinion, if the hours of lessons are increased, the teachers will also find more time for such skills. The skill training is more difficult. When the time is short, the skill training is always pushed to the background (...) (Geography, 0-5 Years, Female)."

Some of the social studies teachers made recommendations on teacher education. A teacher made the following statements on this issue:

"I say a fish rots from the head down. First you must look at your teacher. Is he/she sufficient that you expect your students to do something (!) Train the teacher that is going to give this education to the students well, so he/she can also train his students well (...) The teachers need to educate themselves in this matter, 
certainly. Otherwise, the failure is inevitable (...) (Social Studies, 0-5 Years, Male)."

One of the teachers suggested that the relevant materials should be prepared and delivered to the teachers. Teacher's opinion on this issue is as follows:

"This region is a place where the families from the rural areas come from. It happens to be difficult for me to prepare [table, graphic, diagram] to 30-35 students one by one. In such a crowded class, we study only the main necessities of a lesson. We cannot have them do such studies. For this reason, I suggest that the presentations about the tools and materials that we can use in the classrooms should be send to us (...) (Social Studies, 6-10 Years, Female)."

One of the geography teachers suggested that the teachers of different lessons should cooperate. Some views of the teacher are as follows:

“(...) I think, not only the geography teachers but also others need to use them frequently in their lessons. This is essential for the insufficiency of the students. While a war is taught in the history lesson, the number of soldiers, materials etc. must be explained with tables. The gained territories must be turned into graphics. So it can be used in the mathematics lesson, too (...) (Geography, 6-10 Years, Female)."

\section{Conclusion and Discussion}

In order to train the qualified people that they can take their place in the new world order, it is expected from the education systems to frequently reforms themselves in parallel with the changes. Among these reforms, one of the topics that need to be taken into consideration primarily is the skill training. The TGDI-PS is the skill that is found to be common for both geography and social studies lessons. It is expected that the foundations must be established with the social studies lessons in the secondary school and reinforced with the geography lessons at the high school level. The determination of both the geography and the social studies teachers' views, expectations and the difficulties that they experience about this skill that requires a gradual process is the main purpose of this study.

According to the findings of the data in the questionnaire, the teachers' views on the specific skill are generally positive. It was found that the gender difference was not effective in the views of the teachers. On the opposite, the views of the social studies teachers about this skill were found to be more positive, compared to the geography teachers. The findings, collected from the semi-structured interview data, revealed that the social studies teachers used the related skill in the in-class applications lesser than the geography teachers. Within this scope, it can be interpreted as no matter how much positive the views of the social studies teachers are, they cannot be turned into behaviors. The social studies lesson is a lesson that is on the basis of the scientific data of different social sciences. Within the frame of this lesson, the related skill applications can be given place in a wide range. For example, the government types in the world can be taught to the students with a table, the development phases of the human rights with a graphic, the taxation types with a table, the data about the information technologies 
that are used at home with a pie chart or the climate information with a column chart. It is possible to multiply these examples. Within this scope, it can be said that the social studies teachers cannot use the great sources that they can access. The skill in question requires a gradual curricular process. Students are expected to establish a foundation for this skill with the social studies course at the secondary school level, and to build on this foundation with the geography course at the high school level. Nevertheless, the statements of the teachers show that the social studies course fails to form the basis for the adequate acquisition of this skill. Most of the students are required to demonstrate skills to create tables, graphics and diagrams for first time at the high school level, which oftentimes hampers the fulfillment of the requirements of the geography course.

The social studies and geography teachers stated that they use the tables the most and then the graphics in their lessons. The teachers also stated that they do not prepare diagrams and have the students prepare them. There are two factors in the creation of this situation, according to the teachers. The first one of these factors is lack of knowledge of teachers on diagrams, and the second one is that it is more difficult to access the diagram visuals as materials. Among the main reasons of the fact that the diagrams are less visible for the teachers is that the teachers adhere to the textbooks for the given skill and there are mostly tables and graphic visuals given place in the lesson books. This finding is a sign of the fact that this skill, predicted in the education programs of the lessons, cannot be ensured to be acquired by the students.

Another one of the important results of the study is that the TGDI-PS can only be achieved at the level of interpretation for the students. It is because the teachers take the tables and graphics from the ready-made materials (from the textbooks and few external sources) more. The teachers do not feel competent in terms of material preparation, in relation with this skill. Therefore, they do not have the students prepare materials as they do not prepare them, themselves. In fact, this finding shows that the 'preparation/drawing' statements, given in the education programs, are not performed.

Another interesting finding of the study was the matter of whether the teachers feel themselves sufficient about this skill. The teachers stated their views as "I agree" about the statement of 'I feel myself sufficient' (14th item) and about the statement of 'the number of in-service training and seminars must be increased' (15th item), in terms of the related skills that are included in the questionnaire form. An individual that feels sufficient about a topic would not want to take more in-service training or seminars about that topic. In this matter, it can be said that there is a discrepancy between the answers that the teachers gave to the items. Furthermore, it was found that the teachers stated a view about feeling themselves insufficient during the interviews. In the light of these findings, it can be said that the teachers are generally insufficient in terms of the TGDI-PS.

The TGDI-PS is an interdisciplinary skill. There are the scientific process skills in the science lessons (MoNE, 2018c); visual literacy in the Turkish language lessons (MoNE, 2018d); and basic mathematics skills in the mathematics lesson (MoNE, 2018e). It was also understood that some teachers had a false positioning in their minds about this skill. For example, a social studies teacher stated that he considered this skill 
as the field of the mathematics. The related skill is included in the education both of the programs of the social studies lessons that were published in 2005 (MoNE, 2005) and 2018 (MoNE, 2018b). This finding is a sign for the fact that the teacher did not examine his own education program. Artvinli and Kaya (2010) states that a considerable number of the teachers plans and applies their lessons without examining the education programs. In this matter, this finding supports the findings of Artvinli and Kaya (2010). On the other hand, a geography teacher, who positions this skill correctly, advised the teachers of different fields to cooperate in terms of the related skill. The previous studies that were made in the literature suggest that this skill is interdisciplinary and the teachers need to work in cooperation (Alacac1, Lewis, O'Brin \& Jiang, 2011; Maden \& Altunbay, 2016; Shah \& Hoeffner, 2002; Şahinkaya \& Aladağ, 2013). According to Shah and Hoeffner (2002), the students will learn graphic, table and diagram types in a great variety thanks to approach the same skill in various lessons. Therefore, they will be able to use many types of the graphic organizers.

Dönmez et al. (2007) state that the social studies teachers' remarking that the students cannot establish a meaningful relation between the topics due to the business of the social studies program. Madeleine \& Sekeres (2006) state that the number of concepts are too many within the scope of the geography lesson and this situation makes it difficult for the students to learn. Zaini et al. (2010) state that the graphic organizers are more effective than such tools and activities as underlining, note taking, discussion and group study in terms of learning and remembering. Ben-David (2002) also similarly draw attention to the fact that the graphic organizers give more effective results, compared to the different strategy and education tools. In the study that was made by Dönmez et al. (2007), it was found that learning was achieved more in the classes where these skills are used. In this matter, in order to benefit from the advantages that are also mentioned above, it is thought that it is important to use the graphic organizers both for the social studies and the geography lessons.

Sönmez and Koç (2013) state that the TGDI-PS in the social studies lesson is limited with the intramural applications; and the extramural learning activities were ignored. It is thought that it is important that the teachers must give place to this skill in the extramural activities in a manner that supports the intramural learning, particularly.

Today, the textbooks still continue to be the reference source both for the students and the teachers (Artvinli, 2009; Artvinli \& Kaya, 2010). As it is understood from the statements of the teachers whose opinions were taken, the main source in ensuring skill acquisition is the textbooks for the teachers. In the studies that were made by Artvinli (2009) and Artvinli \& Kaya (2010), the textbooks of the geography 9th and 11th grades were examined in terms of skills. The textbooks of the both grade levels were found to be insufficient qualitatively and quantitatively. Similarly, Robinson (1997) and BenDavid (2002) also state that the textbooks are not at the desired level in terms of tables, graphics and diagrams. In this matter, it will be an accurate approach to reconsider the skills that are included in the geography and social studies textbooks. Furthermore, it is thought that it will be also beneficial to create and provide material pool that the teachers can use for the skill activities to their service. 
TGDI-PS offers benefits to students in many ways, such as facilitating understanding, concretizing abstract information, showing relationships between concepts, problem solving, and perceiving change and continuity. To date, there has been no research on the TGDI-PS competence. In future research, the competence in this skill can be tested by using various measurement and evaluation techniques. In addition, it is one of the fundamental issues to determine which kinds of graphic organizers for the social studies and geography lessons are more convenient for the ages and readiness of the students. In the literature, it is also thought that comprehensive studies are needed in this matter. While determining the table, graphic and diagram types that are going to take place in the textbooks, these study results can be benefited from. It is thought that both the study's functionality and the education's quality can increase by this means.

If teachers do not understand the importance and necessity of the TGDI-PS, how can we expect them to have the students perform these skills with a high degree of accuracy? Due to this reason, the in-service trainings and seminars must be provided to the teachers. In addition to this, the teacher candidates who are continuing their undergraduate education should also be equipped with the table, graph, and diagram interpretation and preparation skills through various activities as part of the 'skill education course.' This study is limited to the views expressed by social studies and geography teachers. Therefore, the results were based on the explanations of only geography and social studies teachers. To better determine the current status of this subject, the opinions and practices of teachers teaching subjects other than geography and social studies about developing the table, graph and diagram interpretation and preparation skills can be investigated in future studies.

\section{References}

Alacaci, C., Lewis, S., O’Brien, G. E. \& Jiang, Z. (2011). Pre-service elementary teachers' understandings of graphs. Eurasia Journal of Mathematics, Science \& Technology Education, 7(1), 3-14.

Alvermann, D. E. \& Boothby, P. R. (1986). Children's transfer of graphic organizer instruction. Reading Psychology, 7(2), 87-100. DOI: 10.1080/0270271860070203

Artvinli, E. (2009). Coğrafya programının öngördüğü coğrafi becerilere 9. sınıf coğrafya ders kitabında erişi düzeyi. Erzincan Eğitim Fakültesi Dergisi, 11(2), 51-66.

Artvinli, E. \& Kaya, N. (2010). Ortaöğretim coğrafya 11 ders kitabının coğrafi becerileri gerçekleştirebilme düzeyi. Türkiye Sosyal Araştırmalar Dergisi, 14(1), 305-320.

Aydın, A. \& Tarakçı, F. (2018). Fen bilimleri öğretmen adaylarının grafik okuma, yorumlama ve çizme becerilerinin incelenmesi. İlköğretim Online, 17(1), 469-488.

Bean, T. W., Singer, H., Sorter, J., \& Frazee, C. (1986). The effect of metacognitive instruction in outlining and graphic organizer construction on students' comprehension in a tenthgrade world history class. Journal of Reading Behavior, 18(2), 153-169.

Bektaş-Öztaşkıran, Ö. (2014). Grafik örgütleyicilerinin sekiz türü ile sosyal bilgiler öğretimi: akademik başarı ve başarı yönelimlerine etkisi. Uluslararası Avrasya Sosyal Bilimler Dergisi, 5(14), 83-109. 
Ben-David, R. (2002). Enhancing comprehension through graphic organizers, Kean College of New Jersey. (ERIC Document Reproduction Service No. ED461907).

Braselton, S. \& Decker, B. C. (1994). Using graphic organizers to improve the reading of mathematics. The Reading Teacher, 48(3), 276-281.

Boothby, P.R. \& Alvermann, D. E. (1984). A classroom training study: the effects of graphic organizer instruction on fourth graders' comprehension. Reading World, 23(4), 325-339. DOI: $10.1080 / 19388078409557783$

Budanır, T. (2004). Coğrafya öğretiminde görsel araçlardan grafiklerin etkili ve yerinde kullanımı (Türkiye'de nüfus konuları örneği ile) (Yayımlanmamış yüksek lisans tezi), Gazi Üniversitesi Eğitim Bilimleri Enstitüsü, Ankara.

Cassidy, J. (1989). Using graphic organizers to develop critical thinking. Gifted Child Today, 12(6), 34-36.

Casteleyn, J. \& Mottart, A. (2012). Presenting material via graphic organizers in science classes in secondary education. Procedia - Social and Behavioral Sciences, 69, 458-466. DOI: 10.1016/j.sbspro.2012.11.434

Creswell, J. W., \& Plano Clark, V. L. (2007). Designing and conducting mixed methods research. Thousand Oaks, CA: SAGE

Darch, C. B., Carnine, D. W. \& Kameenui, E.J. (1986). The role of graphic organizers and social structure in content area instruction. Journal of Reading Behavior, 18(4), 275-295.

Demirci, N. \& Uyanık, F. (2009). Onuncu sınıf öğrencilerinin grafik anlama ve yorumlamaları ile kinematik başarıları arasındaki ilişki. Necatibey Faculty of Education Electronic Journal of Science and Mathematics Education, 3(2), 22-51.

Doyle, C. S. (1999). The use of graphic organizers to improve comprehension of learning disabled students in social studies. Research Project, Kean College of New Jersey. (ERIC Document Reproduction Service No. ED427313).

Dönmez, C., Yazıcı, K. \& Sabancı, O. (2007). Sosyal bilgiler derslerinde grafik düzenleyicilerin kullanımının ögrencilerin akademik bilgiyi elde etmelerine etkisi. Türk Ĕgitim Bilimleri Dergisi, 5(3), 437-459.

Dunston, P.J. (1991). A critique of graphic organizer research. Reading Research and Instruction, 31(2), 57-65.

Gallavan, N. \& Kottler, E. (2007). Eight types of graphic organizers for empowering social studies students and teachers. The Social Studies, 98(3), 117-128, DOI: 10.3200/TSSS.98.3.117-128.

Gieselmann, S. (2008). Graphic organizers in the social studies classroom: effective content integration tools for preservice teachers. Kentucky Journal of Excellence in College Teaching \& Learning, 6, 19-30.

Gültekin, C. \& Nakiboğlu, C. (2015). Analysis of high school chemistry textbooks in terms of graphs and graph-related activities. Dumlupinar University Journal of Social Sciences, $43,211-222$.

Güneş, F. (2012). Bologna süreci ile yükseköğretimde öngörülen beceri ve yetkinlikler. Yüksekögretim ve Bilim Dergisi, 2(1), 1-9. DOI: 10.5961/jhes.2012.026 
Griffin, C. C., Malone, L. M. \& Kameenui, E. J. (1995). Effects of graphic organizer instruction on fifth-grade students. The Journal of Educational Research, 89(2), 98-107. DOI: 10.1080/00220671.1995.9941200

Hall, C., Kent, S. C., McCulley, L., Davis, A., \& Wanzek, J. (2013). A new look at mnemonics and graphic organizers in the secondary social studies classroom. Teaching Exceptional Children, 46(1), 47-55.

Hall, T., \& Strangman, N. (2008). Graphic organizers. Retrieved from https://www.northernhighlands.org/cms/lib5/nj01000179/centricity/domain/18/graphic_or ganizers_2008.pdf

Hawk, P. P. (1986). Using graphic organizers to increase achievement in middle school life science. Science Education, 70(1), 81-87.

Ives B. \& Hoy, C. (2003). Graphic organizers applied to higher-level secondary mathematics. Learning Disabilities Research \& Practice, 18(1), 36-51.

İlter, İ. (2016). The power of graphic organizers: effects on students' word-learning and achievement emotions in social studies. Australian Journal of Teacher Education, 41(1), 42-64.

Jiang, X. (2012). Effects of discourse structure graphic organizers on EFL reading comprehension. Reading in a Foreign Language, 24(1), 84-105.

Johnson, R. B.; Onwuegbuzie, A. J. \& Turner, L.A. (2007). Toward a definition of mixed methods research. Journal of Mixed Methods Research, 1(2), 112-133.

Knight, V. F., Spooner, F., Browder, D. M., Smith, B. R. \& Wood, C. L. (2013). Using systematic instruction and graphic organizers to teach science concepts to students with autism spectrum disorders and intellectual disability. Focus on Autism and Other Developmental Disabilities, 28(2), 115-126.

Kohler, P. (2009). Don't just tell me; show me: Using graphic organizers effectively. Teaching Professor, 23(6), 1-7.

Madeleine, G. \& Sekeres, D. C. (2006). My word! Vocabulary and Geography Learning. Journal of Geography, 105(2), 53-58, DOI: 10.1080/00221340608978661

Maden, S. \& Altunbay, M. (2016). Türkçe eğitiminde görsel sunu ve görsel okuma aracı olarak grafik ve tabloların kullanımı. Uluslararası Türkçe Edebiyat Kültür Eğitim Dergisi, 5(4), 1971-1983.

Memnun-Sezgin, D. (2013). Examining of line graphic reading and drawing skills of secondary school seventh grade students. Turkish Studies, 8(12), 1153-1167.

Meyer, D. J. (1995). The effects of graphic organizers on the creative writing of third-grade students. Kean College of New Jersey. (ERIC Document Reproduction Service No. ED380803)

Miles, M. B., \& Huberman, A. M. (1994). Qualitative data analysis: An expanded sourcebook. Thousand Oaks, CA: SAGE.

Ministry of National Education-MoNE (2005). Sosyal bilgiler dersi ögretim programı, Ankara: Devlet Kitapları Müdürlügü.

Ministry of National Education-MoNE (2018a). Ortä̈ğretim cŏgrafya dersi (9, 10, 11 ve 12. sinıflar) ögretim programı, Ankara: Devlet Kitapları Müdürlüğü.

Ministry of National Education-MoNE (2018b). Sosyal bilgiler dersi ögretim programı (ilkokul ve ortaokul 4, 5, 6 ve 7. sinıflar), Ankara: Devlet Kitapları Müdürlüğü.

Ministry of National Education-MoNE (2018c). Fen bilimleri dersi öğretim programı (ilkokul ve ortaokul 3, 4, 5, 6 ve 7. sinıflar), Ankara: Devlet Kitapları Müdürlüğü. 
Ministry of National Education-MoNE (2018d). Türkçe dersi ögretim programı (ilkokul ve ortaokul 1, 2, 3, 4, 5, 6 ve 7. sinıflar), Ankara: Devlet Kitaplar1 Müdürlüğü.

Ministry of National Education-MoNE (2018e). Matematik dersi ögretim programı (ilkokul ve ortaokul 1, 2, 3, 4, 5,6 ve 7. sinuflar), Ankara: Devlet Kitapları Müdürlüğü.

Monroe, E. E. (1997). Using graphic organizers to teach vocabulary: Does available research inform mathematics instruction? (ERIC Document Reproduction Service No. ED414256)

Moore, D. W., \& Readence, J. E. (1984). A quantitative and qualitative review of graphic organizer research. Journal of Educational Research, 78(1), 11-17.

Oruç, Ş. \& Akgün, İ. H. (2010). The acquisition level of graphic reading skills of elementary social studies 7th grades students. Uluslararası Avrasya Sosyal Bilimler Dergisi, 1(1), 5158 .

Oruç, Ş., Uğurlu, N. \& Tokcan, H. (2010). Using graphic illustrations with social studies textbooks. Procedia Social and Behavioral Sciences, 2, 1037-1042.

Robinson, D. H. (1997). Graphic organizers as aids to text learning. Reading Research and Instruction, 37(2), 85-105, DOI: 10.1080/19388079809558257

Ping, Q. (2016). Graphic Organizers in Reading Instruction: Why and What Merits Attention? Studies in Literature and Language, 13(6), 38-41.

Schenning, H., Knight, V. \& Spooner, F. (2013). Effects of structured inquiry and graphic organizers on social studies comprehension by students with autism spectrum disorders. Research in Autism Spectrum Disorders, 7, 526-540.

Sezer, A. (2017). Coğrafya öğretiminde grafiklerin kullanımı. Adem Sezer (Ed.), in Coğrafya ögretim teknolojileri ve materyal tasarımı, (p.163-183). Ankara: Pegem Akademi.

Simmons, D., C.; Griffin, C. C. \& Kameenui, E. J. (1988). Effects of teacher-constructed preand post-graphic organizer instruction on sixth-grade science students' comprehension and recall. The Journal of Educational Research, 82(1), 15-21, DOI: $10.1080 / 00220671.1988 .10885859$

Shah, P. \& Hoeffner, J. (2002). Review of graph comprehension research: implications for instruction. Educational Psychology Review, 14(1), 47-69.

Sönmez, Ö. F. \& Koç, H. (2013). Sosyal bilgiler öğretiminde harita, grafik ve tablo kullanımı. Ramazan Sever, Erol Koçoğlu (Editörler), Sosyal Bilgiler Öğretiminde Eğitim Teknolojileri ve Materyal Tasarımı, İçinde (p.187-207) Ankara: Pegem Akademi.

Şahin, S., Gençtürk, E. \& Budanur, T. (2007). Coğrafya öğretiminde uygun grafik seçimi ve kullanımının öğrenme üzerindeki etkisi. Kastamonu Eğitim Dergisi, 15(1), 293-302.

Şahinkaya, N. \& Aladağ, E. (2013). Sınıf öğretmen adaylarının grafikler ile ilgili görüşleri. Adıyaman Üniversitesi Sosyal Bilimler Enstitüsü Dergisi, 6(15), 309-328.

Taş, H. İ. (2008). Coğrafi beceriler ve bunların öğrencilere kazandırma yolları. Doğu Coğrafya Dergisi, 13(20), 45-58.

Taşdemir, A., Demirbaş, M. \& Bozdoğan, A. E. (2005). Fen bilgisi öğretiminde işbirlikli öğrenme yönteminin öğrencilerin grafik yorumlama becerilerini geliştirmeye yönelik etkisi. Gazi Üniversitesi Kırşehir Eğitim Fakültesi Dergisi, 6(2), 81-91. 
Yazıc1, K. (2006). Sosyal bilgilerde kullanılan görsel araçlar: Haritalar-küreler, resimler, tablolar ve grafikler. Selçuk Üniversitesi Sosyal Bilimler Enstitüsü Dergisi, 15, 651-662.

Yavuz, İ. \& Kepceoğlu, İ. (2010). Öğrencilerin fonksiyonlarda işlemler konusuna grafikler üzerinden yaklaşımlarının incelenmesi. Sakarya Üniversitesi Ĕ̈itim Fakültesi Dergisi, 20, 59-80.

Zaini, S.H., Mokhtar, S.Z. \& Nawawi, M. (2010). The Effect of Graphic Organizer on Students' Learning in School, Malaysian Journal of Educational Technology, 10(1), 17-23.

Zollman, A. (2009). Students use graphic organizers to improve mathematical problem-solving communications. Middle School Journal, 41(2), 4-12, DOI:10.1080/00940771.2009.11461707

\section{Biographical statement}

Fitnat GÜRGÍL is a research assistant doctor at Gazi University, Gazi Faculty of Education. Her works focuses on social studies education, interdisciplinary programs and cultural education. 